\title{
$20 \quad$ Public Social Science at Work: Contesting Hostility Towards Nicaraguan Migrants in Costa Rica
}

\author{
Carlos Sandoval-García ${ }^{1}$
}

\begin{abstract}
$^{2}$
Nicaraguan migration to Costa Rica is one of the most salient cases of South-South migration in Latin America. Despite Costa Rica's self-representation as a peaceful and democratic society, Nicaraguan migrants in Costa Rica, the main foreign-born community in the country, are widely portrayed in derogatory terms, for example as violent and criminal and in general as "threatening Others" (Sandoval 2004). This chapter explores a set of examples of analyses of critical interventions - regarding immigration law, social imaginaries around which representations of Nicaraguans are framed, and participatory work carried out with impoverished communities in order to reflect on the ways in which social sciences in Costa Rica attempt to intervene both in the everyday hostility of Costa Rican society and in the ways in which Nicaraguans contest that hostility. Responding to Michael Burawoy's call for a "public sociology" $(2005,2007)$, the chapter reflects on how debates around public social sciences could enrich the political, institutional, and conceptual location of migration studies in Costa Rica.
\end{abstract}

Keywords: migration, Nicaraguans, Costa Rica, immigration law, social imaginaries, community work, public sociology.

\subsection{Introduction}

This chapter ${ }^{3}$ reflects on the scope and limitations of endeavouring as social researchers and social activists to intervene in three specific arenas of the debate on immigration in Costa Rica. One refers to the possibilities of influencing public policy in the field. The experience of analyses of Costa Rica's new Migration and Alien Affairs Law, which came into effect in March 20IO, is discussed. The main challenge has

1 Carlos Sandoval-García is professor at the Media Studies School and the Institute for Social Research, both at the University of Costa Rica. He is also editor of the Anuario de Estudios Centroamericanos (<www.anuario.ucr. ac.cr $>$ ).

2 This chapter draws on the findings of an IDRC-funded project 'Advancing the Rights of Migrant Women in Latin America and the Caribbean', project number I04785-003.

3 An earlier version of this chapter (Sandoval, 20I2a) was published in Entreverse. Teoría y metodología práctica de las Fuentes orales, edited by Miren Llona (Bilbao, University of the Basque Country). been how to translate the analysis of social sciences into a legal submission to the Constitutional Court. A second area is how to respond to the imaginaries of immigration, which are usually characterized by an exaggeration of the number of immigrants and by imputing to them the weakening of public services and the rise of insecurity. A third area of intervention refers to work with migrant communities and the ways they position themselves with respect to the criminalizing discourses they are questioning.

Reflection about the challenges, institutionalization, and links with the social sciences has been present in different periods and sociocultural contexts. Often it has involved critical observations growing out of the context of power relations that privilege certain perspectives and institutional contexts to the detriment of others (see, for example, Fanon (1986), Mills (1987)). Some of these initial concerns have continued to be debated more recently. Pierre Bourdieu and Wacquant (I992: 37), for example, suggest at least three angles of inquiry. One refers to the social origins and social conditions (e.g. class, gender, generation) from which a researcher envisions a project; the 
second asks about the institutional conditions from/ in which it is worked on; and the third refers to the concepts and tools from which and with which it is conceptualized and developed. The three demand an effort of distancing capable of converting the biography and premises of work into an object of inquiry. Boaventura de Sousa Santos (2009: I25) offers a second contribution, suggesting that reality cannot be reduced to what exists, but requires also a sociology of what is missing and a sociology of what is emerging. ${ }^{4}$

A third perspective, upon which this chapter is mainly based, is Michael Burawoy's call for public sociology, a sociology which addresses wide publics and asks for whom and for what knowledge is being produced. Burawoy (2007: 243) identifies four spaces of sociology: professional sociology, written for other specialists, which has the greatest legitimacy and recognition; the sociology of public policies; critical sociology; and the one he underscores as the main challenge, public sociology. Some critics have reservations about whether public sociology will effectively be able to subvert the hierarchies within the discipline (Hays 2007); others ask how far public sociology recognizes the asymmetries between sociology and subordinate fields of knowledge, such as Latino studies or ethnic studies (Nakano Glenn 2007). A greater doubt is to what degree this debate about public sociology enters into a dialogue with similar perspectives in the global South (see Burawoy 2007: 254 for an exception).

Following Patricia Hill Collins (2007: 2I), this chapter asks whether and how we who work critically in migration have "been making public sociology without knowing it" (emphasis in the original). It asks too in what ways these debates are enriching our work in a period in which the institutional weaknesses of the Central American universities and the predominance of international cooperation priorities leave few possibilities for new generations of social scientists to be able to enjoy stable work options from which they can respond to the needs for knowledge of the dispossessed peoples in the region.

Both the views of de Sousa Santos and Burawoy require us to reflect on the ways in which power/ knowledge relations are forged in migration research.

4 De Sousa Santos (2009: I29) suggests a sociology of absences and a sociology of emergences. "While the sociology of absences moves in the field of social experiences, the sociology of emergences moves in the field of social expectations" (p. I30). "Both grant the present a denser and more substantive content than the fleeting instant between past and future" (p. I3I).
Issues regarding needs of knowledge and political organization of migrant communities and the interplay between research, advocacy, and policy-making are among some of the challenges posed by these attempts to go beyond detached social science research.

The three areas of work considered in the chapter - public policies, social imaginaries, and community work - have been part of research projects carried out at the Institute for Social Research at the University of Costa Rica between 2005 and 20II. ${ }^{5}$ We began working on a project whose title was La Carpio: The experience of urban segregation and social stigmatization, which was supported by a grant awarded by the Wenner-Gren Foundation for Anthropological Research and another from the Central American Jesuit Migration Service (Sandoval/Brenes/Fernández/Paniagua/ Sánchez 2007; Sandoval 2009a; Sandoval/Brenes/ Masís/Paniagua 20IO; see also <www.lacarpioenlinea.ucr.ac.cr $>$ ). The La Carpio community is probably the biggest binational community in Central America and the project aimed to contribute towards building collective memories and a grounded political culture.

A second team project was Advancing the Rights of Migrant Women in Latin America and the Caribbean, a regional project that has looked at the lived experience of migrant women and migrant organizations in five Latin American countries, one of which was Costa Rica. This project was funded by the International Development Research Center (IDRC) of Canada (Brenes/Fernández/Paniagua/Sandoval 20Io; Bolaños/Brenes/Paniagua/Sandoval et al. 20II; Sandoval/Brenes/Paniagua 20I2). We aimed not only to research some of the main issues regarding migration, but also to learn how to build cooperative forms of work in which collaboration and not competition could be the main source of inspiration. The challenges of the social sciences not only refer to the formulation of theoretically and empirically (and socially relevant) informed research questions, but also depend on the possibility of forging vibrant, generous, and enriching academic cultures (Green 1997: 195). Meanwhile, these projects have asked the team how to build links: with migrant people who, rather than

5 During this period, a number of colleagues have been active protagonists. Esteban Sánchez-Solano, Mayela Castillo-Villachica, Karen Masís-Fernández, Marcela Montanaro-Mena, and Olman Bolaños have joined several initiatives. Mónica Brenes-Montoya, Laura Paniagua-Arguedas and I have worked together throughout this period. 
being considered as 'objects of research', are recognized as subjects; with organizations that work on advocacy; and with cooperation agencies.

\subsection{Nicaraguan Migrants as 'Threatening Others' in the Costa Rican Social Imaginary}

The Nicaraguan community in Costa Rica is a major case of South-South migration in the Latin American context. The 2000 population census estimated that Nicaraguans who live in Costa Rica represent around 226,374 (5.9 per cent) of the total inhabitants. Eleven years later, in 20II, the population census reported $287,766,6.6$ per cent of the total population. Over the course of a decade (2000-20I0), while there was a 27.I per cent absolute rise there was thus only a very slight increase in the share ( 0.9 per cent), which is much less prominent than the one reported between the census carried out in 1984 and the 2000 census, which was 4.I per cent. In other words, there is a tendency towards stabilization of Nicaraguan immigration in Costa Rica, although in the Costa Rican imaginary the image is that the proportion of immigrants is continuing to grow.

In the second half of the twentieth century, two moments can be distinguished in which the displacements from Nicaragua to Costa Rica intensified. One was the war in Nicaragua financed by the Reagan Administration starting in the early eighties, which demanded the establishment of Patriotic Military Service (conscription) and produced a profound economic crisis in Nicaraguan society. The other was generated by the neo-liberal measures starting in the early nineties that privatized institutions in Nicaragua, eliminated subsidies, and generated enormous unemployment. Additionally, the social disaster produced by Hurricane Mitch in 1998 aggravated the living conditions of hundreds of thousands of Nicaraguans.

The Nicaraguan community in Costa Rica has been thematized as much in the media as in everyday life conversations. Many of the themes will seem familiar in other countries and regions, since while nationalities vary, the narratives do not: Will the immigrants become a majority? Will they impose other customs? Will they take jobs away from the nationals? Are they responsible for the decline of public services and the increase in crime rates and the sense of insecurity? These are some of the recurring questions heard in Costa Rica, just as in the United States or the
European Union (Lipsitz I999; Chavez 200I, 2008; Bhattacharyya/Gabriel/Small 2002).

In the case of Costa Rican society, a weak public sphere impedes a strengthening of reflection about itself and of any recognition that there has been an undermining of key institutions, generated above all by the shrinking of public investment and by a blurring of the collective imaginary that has characterized the country as 'exceptional'. Fantasies about the nation frequently replace debate about the type of society to which one aspires. The anti-immigrant hostility, often fed by the mass media, has been the raw material of the exclusionary fantasies of the nation. In turn, this same anti-immigrant hostility aims to contain and make bearable the anxiety generated by the uncertainty about the effacing of the institutions and the imaginaries (Sandoval 2004).

During the last thirty years, Costa Rica has experienced a number of changes in its economic policies which have configured an export-based economy that has diversified products and increased markets. Under this economic pattern, economic growth has not meant equitable redistribution. While the proportion of those living below the poverty line remains at about twenty per cent, inequality has risen considerably. A new methodology applied to estimating income distribution reported that the Gini Index is about 0.54 per cent (INEC 20II). It locates Costa Rica as one of the Latin American countries in which inequality has risen more sharply in recent years.

Paradoxically, those who are considered 'threatening Others' are indispensable for these new economic patterns. Newer leading agricultural products like watermelons, oranges, melons, and mangoes, as well as traditional products such as coffee and bananas, are produced and processed by Nicaraguan men and women. The case of the construction sector is similar, since Nicaraguans have been indispensable for building the infrastructure that has made possible the tourist boom, especially in the Pacific coast region. Insecurity, which has been considered as the main problem of the country in a number of surveys, has been tempered by private security companies which very often recruit Nicaraguan guards. Throughout this period, 'security' has ceased to be seen as an issue related to the Costa Rican welfare state and has become instead a police concern. Meanwhile, attributing responsibility for this sense of dislocation to Nicaraguans has been a way of making sense of these institutional changes. Last but not least, Nicaraguan women are in charge of (badly-)paid domestic work and responsible for caring for Costa Rica's middle-class children and 
elderly people. In short, those who are considered violent are also the ones responsible for maintaining Costa Rica's sense of security and economic growth. The increase in drug trafficking and political corruption makes this landscape even more unpredictable (Sandoval 20I2c).

\subsection{Understanding and Countering the Legality that Produces Irregularity - Analytical, Normative, and 'Translation' Research}

Seyla Benhabib (2004: 2) has noted that "transnational migrations bring to the fore the constitutive dilemma at the heart of liberal democracies between sovereign self determination claims on the one hand and adherence to universal human rights principles on the other". It is recognized that there are human rights that transcend national policies but it is also recorded that the sovereignty of the state continues to determine who has rights and who does not.

Costa Rica's current General Law of Migration and Alien Affairs (No. 8764) was approved by the Legislative Assembly in July 2009 and went into effect in March 20IO. In general, it presents a series of modifications to the previous law. It eliminates a good part of the vocabulary linked to 'security' which abounded in the earlier law, replacing it with that of human rights, alluding to multiple international agreements ratified and in effect in Costa Rica.

The human rights framing has earned important legitimacy among stakeholders. But the new law combines this framing with specific provisions that make the migratory regularization process even more cumbersome and difficult, and grants competencies to authorities charged with executing the migratory legislation that more properly belong to the judicial branch.

Even though Costa Rican Social Security reports that only 57.4 per cent of the economically active population was covered by social security as of February 2009, mainly because the majority of jobs generated are located in the so-called 'informal' sector, affiliation to the public social security system is one of the new requisites for beginning regularization processes (articles 7, point 7; 78, point 3; and 97). A consequence of this new requisite is that the responsibility for insurance falls on the workers and employers are exempted of their responsibility.

The costs related to documentation are another aspect. The law establishes a series of payments to ob- tain extension periods for the migratory category or to change it. For example, persons categorized as tourists must pay US\$Ioo to prolong their stay in the country (article 90). In addition, those wishing to change their migratory category must, in addition to meeting the requirements to obtain the new category, pay \$200 (articles 96 and I25) unless they leave the country to come in on a visa, in which case they must begin residency proceedings, which costs $\$ 30$.

If one considers that the high costs are one of the factors that impede the steps for regularizing the migratory status or renewing documents, they become a factor that impedes regularization itself. In fact, one of the grounds to cancel a person's permanent residency is failure to renew that person's documentation within three months of its expiry date (article I29, point IO). To this must be added that for every irregular stay in Costa Rican territory, once must pay a US\$roo fine for each month of that stay or, "by default, the person's entry will be prohibited for a period equivalent to triple the time of his/her irregular permanence" (article 33, point 3).

The insurance requirement added to the severity of the fines will very probably increase non-documentation. Thus the law would produce the 'illegality' it is claimed it would eradicate; that is, the requisites are such that they foster lack of documentation. The report of regularization requests presented to the General Division of Migration and Alien Affairs (DGME) reveals that there has been a decrease of almost fifty per cent in new permanent visa applications between $20 \mathrm{IO}$ and 20II (Press Conference 20I2). In other words the law's promise, which is regulation, is far from being fulfilled. ${ }^{6}$

The same pattern is underscored in some studies on migratory legislation in various other countries (DeGenova 2002). Mae Ngai, for example, has noted

6 During the second semester of the year 20I2, the DGME announced a number of temporary measures that make some of the requirements for residence more flexible. It coincided with the recognition of the Tratado de la Apostilla, which establishes that when a state recognizes documents expedited by another state, such documents do not need to be certified by the consular authorities of the country in which they are going to be submitted. Currently, Nicaraguans applying for residency in Costa Rica can obtain their documents at the Nicaraguan consulate in Costa Rica. The large queues at the Nicaraguan consulate seem to confirm that most of the undocumented Nicaraguans who live in Costa Rica have already qualified for a visa but have not had the budget to pay for their documents. 
that "the migratory restriction produces an illegal person as a new illegal political subject, whose inclusion within the nation was simultaneously a reality and a legal impossibility". She goes on to say that "being an unauthorized or illegal immigrant is a status conferred by the State and is then incorporated into the bodies of the migrants, because illegality is both produced and experienced" (quoted by Chavez 2008: 23). A law that claims to be inspired in the name of human rights ends up reducing the practical possibilities of achieving migratory regularization.

A second set of provisions foreseen by the law refers to the powers granted to migratory authorities. The detentions that the Migration Police may make are for twenty-four hours, but they can be extended with the authorization of the DGME director without specifying a limit, as established in articles I2 and 3I, points $5 \mathrm{a}$ and $5 \mathrm{~b}$. In this context, doubt arises as to whether the detentions could be indeterminate and prolonged by an administrative authority or are expressly reserved for a judicial authority, as the Political Constitution of Costa Rica makes explicit in its article 37. The provision in article $\mathrm{I} 6$ of the existing Law of Migration and Alien Affairs must be understood in the same sense, namely that "the Professional Migration Police will investigate the trading and trafficking in persons, as well as any infraction of a migratory nature". The administrative police would be given the power of making arrests, but this should not be for the purpose of investigating cases, as this would usurp a power of the judicial branch as established in article I53 of the Political Constitution.

From a more long-range perspective, this discretion granted to administrative authorities coincides with changes in the legislation of a large number of countries, which have meant the erosion of a number of aspects of the rule of law through the greater discretion granted to police authorities and the reduction of the presumption of innocence and of the separation of powers (Bhattacharyya 2008). In the migratory sphere then, changes are taking place whose nature and consequences could be far-reaching.

The construction of links between the different kinds of knowledge, agents, and social practices around the demand for justice and rights in the field of migration requires a search both for ways to articulate perspectives of a more analytical type, which for example describe the increase in policies to control migratory flows, and for approaches whose main attention is applied to a normative perspective and whose priority is to imagine possible modes of transformation.
Spanning the analytical and the normative, one of the tasks still pending is to conceive a public policy on migration that starts by recognizing the profound interdependence between migrants, their relatives, and the receiving communities. Thousands of people have found employment and residence in Costa Rica, providing services to Costa Rican citizens; for example, many Costa Ricans can work at paid jobs because a Nicaraguan is caring for their children or for older adults. Some economic activities, such as construction, export agriculture, private security, and of course paid domestic work structurally depend on the participation of Nicaraguans. Although, as Benhabib (2004: 93) notes, "peoples are radically and not merely episodically interdependent", she emphasizes that "citizenry and the practices of political membership are the rituals through which the nation spatially reproduces itself. The control of territorial borders, which is coeval with the sovereignty of the modern nation state, seeks to ensure the purity of the nation in time through the policing of its contacts and interactions in space" (Benhabib 2004: I8).

For normative-cum-transformative work, rather than suggesting new totalities Boaventura de Sousa Santos (2009: I25) favours the work of 'translation', which he specifies as "the procedure that permits the creation of reciprocal intelligibility among the experiences of the world, both the available and the possible, revealed by the sociology of absences and the sociology of emergences" (de Sousa Santos 2009: I36). Translation involves links between various kinds of knowledge, agents, and social practices and is particularly necessary in the search for links between perspectives of a more analytical kind and those more focused on regulatory approaches. The importance of this link acquires more relevance if one recognizes, as Jonathan Rutherford (2007: I9) has noted, that the predominating theories that emphasize the de- and reconstruction of social identities, generally related to post-structuralism, have lacked the ethical references to generate new, more egalitarian social relations than the ones they seek to deconstruct. The emphasis on the possibility of reconstruction has not been accompanied by a similar impetus in terms of articulating emerging worlds.

Translation also facilitates the configuration of "contact zones" (Sandoval 2009b) between kinds of knowledge, perspectives, and actors who do not frequently encounter each other. Law, says de Sousa Santos (2OIO: I2), "can be emancipating when it is used counter-hegemonically". In other words, the lonely academic critique or the communications from organi- 
zations that recognize discriminations in such law need to be transcended in order to advance the recognition of "citizenries in practice" (Brenes/Fernández/ Paniagua/Sandoval 20ro). The public social sciences, in the Burawoy sense, can contribute to this task.

It is in this context that the challenge arises to try to contest some articles of this law in the Constitutional Court on the grounds of unconstitutionality or because they go against international agreements to which the Costa Rican State is a signatory, arguing, for example, that some of the requisites, costs, and fines violate the principles of reasonableness and proportionality which underpin the rule of law, or that the powers assigned to the DGME and the Migration Police violate the principle of independence of the branches of government.

This involves not only systematizing some of the criticisms of the existing legislation, but also consolidating capacities to persuasively contest the need to make justice and citizens' rights prevail beyond nationality. Based on this concern, the team who worked in the project Advancing the Rights of Migrant Women in Latin America and the Caribbean invited colleagues working in NGOs and churches to reflect on the scope of the law and on the possibilities of engaging in advocacy. In the framework of these initiatives, a document with the main concerns was delivered to the then director of the DGME, in which it was suggested, for example, that the charges for obtaining documents should not be reduced but that the documents should be valid for longer. As a product of this initiative, the DGME agreed to extend the validity of residence permits from one year to two at first issue and to three or four years for revalidations, as verified by article 56 of the Regulations of Alien Affairs published in the official daily La Gaceta in January 20II (Asamblea Legislativa de la República de 2009).

A second stage of the work consisted of convening a group that met over a longer period for a more careful reflection on the law and on the possibilities of preparing a writ of unconstitutionality. By September 20II, a final version of the writ was submitted to the Constitutional Court, which in April 2012 partially admitted it. Overall, the Court admitted the claims against those articles in which the distinctions between faculties of the Judicial and the Executive powers were blurred. But it did not accept that serious criminal charges were a matter of constitutional law. If one compares the work done when the previous law went into effect in 2006 and what happened with the current one, an important difference is that this time there is a greater collective critical effort and ca- pacity for detailed and informed analysis. In fact, in 2006 , the possibility of writing a writ of unconstitutionality was unthinkable. Now the possibility of getting together colleagues from the social sciences and law (a social science that is unfortunately usually far away from the rest of the camp) is a substantive step forward. Even though at the time of writing this chapter (May 20I2), the Court has not provided a final decision, this experience is without doubt a step forward both in terms of cooperative work and translating social science findings into legal claims. Following de Sousa Santos, the writ of unconstitutionality that was presented in 20II might be thought of as a team experience of translating empirical research into a normative perspective through which what was absent (a Constitutional claim) was made possible. Although international cooperation in migration research is frequent and at times abundant, little is invested in promoting advocacy, particularly long-term advocacy. Instead, assessments on diverse themes often overlap. In response to this certainly limited panorama, the experience of analyzing the law introduces more general questions about what the research and advocacy priorities on the migration issue should be in a context characterized by the hardening of migratory legislation in various regions of the world.

A second initiative on the issue of rights has been articulated around the danger that Nicaraguan women with an irregular status do not have access to health services except in emergency situations or during pregnancy. The Costa Rican state is a signatory to the international legislation on sexual and reproductive rights. As a consequence, what is established in these international regulations is obligatory for the Costa Rican state. The challenge is how to make compliance with international regulations enforceable at a national level. A document by the project team $A d$ vancing the Rights of Migrant Women in Latin American and the Caribbean has also been prepared. However, just before submitting the proposal to the authorities, a number of financial and administrative difficulties at the Public Security System (Caja Costarricense de Seguro Social [CCSS]) were revealed which made politically improbable that health provision for non-documented women would be accepted. The Minister of Health even suggested that attention to migrants was one of the factors that explain the financial crisis (La Nación 27.08.20II).

Both the writ of unconstitutionality and the proposal to extend to migrant women in an irregular condition the right of access to health care face hard times due to the conflict over the definition of bor- 
ders between Nicaragua and Costa Rica (Sandoval 20I2c). This ongoing situation involves a considerable step backward in terms of the exercise of migrants' rights. The media have represented the conflict as a confrontation between societies and in Costa Rica flags have even been placed in houses and automobiles to underscore the identification of the population with the position of President Laura Chinchilla. Thus the border conflict has mobilized nationalist speeches and increased anti-migrant hostility. That, together with the exercise of citizenship in practice, presents the enormous challenge of debating the social imaginaries around immigration, some of which are unquestionably a departure point for the legislation that we have discussed in this section. This is the subject of the following section.

\subsection{Social Imaginaries around Immigration -The Absence of Recognition of Interdependence}

In a context of anti-immigrant hostility, one of the challenges facing academic research and social organizations is how to respond to it, both in terms of content and in the cultural forms and means used. This section examines some of the arguments with which an attempt is made to respond to anti-immigrant hostility. A first argument is the 'numbers game,' where it is often suggested that if the number of immigrants drops, the hostility will decrease as well. A second repertoire is instrumental: we must accept the immigrants given that they undertake work the local population does not do. A third way of responding, common among the critical social sciences, is to assume that the hostility is a product of unfounded images about the relationship between the presence of immigrants and insecurity or lack of facilities in the institutions. A fourth way of responding refers to the application of values such as hospitality and solidarity to try and transcend the hostility and exclusion associated with migratory legislation.

The "numbers game" (Hall I98I) is usually used from conservative positions, not so much to refute the hostility as to justify it. Thus the main thesis is that if there weren't 'so many migrants' there would be no hostility. That makes the immigrants responsible for their own discrimination. Ghassan Hage (I998: 92) notes something for the case of Australia that could also be said in the Costa Rican case: when it is considered that there are 'many immigrants', it "represents...the possibility of becoming beyond control and losing the status of being an object of the will of the nationalist manager".

The literature reports that there is not necessarily a correspondence between an increase in immigration and the growth of hostility. It is estimated that international migrants make up three per cent of the total world population, i.e. some 200 million people. It is often considered that such figures correspond to a considerable increase in international migration, frequently explained as a consequence of globalization. Nonetheless, historians (e.g. Hobsbawn 1998) have already noted that in relative terms, taking into account the population at the time, there was greater immigration in the nineteenth century than in the twentieth century. If an analysis of internal migration were integrated into this historical perspective, there might also be some surprising results. From the above, it can be concluded that both in historical terms and in contrasting internal-versus-external migration, greater caution should be used when concluding that we are living in an 'age of migrations', which is often assumed to be a synonym for international migrations. Very probably the most noteworthy aspect of this period is the increase in controls by the developed countries, particularly the United States and the European Union, to avoid the entry of people seen as racially different coming from the countries of Latin America, Asia, and Africa.

The Costa Rican case demonstrates some similarities to what has been noted in international terms. While the 1927 census, for example, reported 6.2 per cent foreign population, the 20 II census reported 8.9 per cent, which means a slight increase in share of 2.7 per cent in 84 years. As was noted above, the increase of the Nicaraguan share between 2000 and 2011 was 0.9 per cent, much less than in the period I984-2000, when the increase was 4.I per cent. In other words, although the local population is falling in Costa Rica, Nicaraguan immigrants are not showing a pronounced increase. Nonetheless, the hostility appears not to be decreasing substantially. In this regard, one of the pending challenges for public social science is how to undertake and communicate a critical reading of the demographic trends with non-specialized audiences.

Instrumental responses, which stress that Nicaraguan men and women take jobs that the local population does not want (Sandoval 2004), are usually the most frequent and advocate tolerance. This vision is based on the premise that crucial economic activities, such as export agriculture (pineapples, oranges, melons, bananas, and coffee, for example), as well as con- 
struction or paid domestic work, depend on the Nicaraguan labour force, and so they must be tolerated. A shortcoming of this concept of tolerance, however, is that those who supposedly propose it retain the right to decide who they exercise their tolerance on; they do not lose the power that allows them to be tolerant. As Hage (1998: 85-86) notes, "When those who are intolerant are asked to be tolerant, their power to be tolerant is not taken away from them. ... the advocacy of tolerance left people empowered to be intolerant".

Recognition of the interdependence between the receiving society and the migrants could be a step forward from a temporary self-interested 'tolerance'. Nonetheless, Costa Rican society is far from being in a condition to recognize how much it depends on those it does not accept. The recognition of interdependence is, in de Sousa Santos' terms, a structuring gap in the Migration Law. In other words, that which is not there tends to shape the part that is. In this regard, the migratory legislation expresses values rooted in the social imaginary, such that trying to change it is not merely a legal issue, although that dimension is very important, but relates to a plane that is more ideological.

The absence of the notion of interdependence also refers to the underdevelopment of the possible narrative or genres from which to represent interdependence. It is symptomatic that in Costa Rica, despite the frequency of references to immigration, only two novels have been published on this theme (Marcenaro 2007; Paniagua 2010), even though novels are possibly the cultural form that best reveals the social reality of a period (Bakhtin I98I; Williams I977; Mora 2000). Nor is there major participation in the public debate about immigration by the first generation of the children of immigrants. They should be among those best prepared to be aware of the centrality of interdependence.

In a context in which the ratio of paid jobs undertaken by women is higher than the proportion of reproductive work done by men at home, a good number of Costa Rican women recognize that without the paid domestic work frequently done by Nicaraguan women, their participation in the job market would be impossible. In a certain way, paid domestic work done by Nicaraguan women has made gender inequalities less explicit in Costa Rican society. However, such recognition does not translate into publicly shared narratives that can frame social imaginaries and policy-making on immigration in terms of interdependence. In such a context, the ways in which Nica- raguan women experience inequalities and misrecognition in Costa Rica is not a publicly recognized issue. For instance, their employers do not affiliate them to the CCSS (it is estimated that only Io per cent of the total paid domestic workers are registered in the CCSS), and so they will not have a chance to obtain health provision and/or a pension.

Despite the fact that most of migrants are not of an age at which they require frequent visits to clinics, 'common sense' hostility in Costa Rica makes sense of the decline in public services (including health) as a consequence of the demand from migrants. The 'Nicaraguan other' is deeply embedded in jokes, emails, interpersonal conversations, blogs, and entertainment programmes. The principal consequence of this conversion is probably that xenophobia and racism have been turned into 'common sense' and few respond to it from a critical perspective in daily life.

These mythologies are not justified by the empirical evidence and instead respond to prejudices that research could reveal. For example, the evidence confirms that there is no causal relationship between the increase in certain forms of criminality and the migrant population. The percentage of incarcerated Nicaraguan men is close to the total percentage of Nicaraguans in the country. The analysis of the association usually established between the decline in public services and the immigrant population has been refuted based on the consideration that this decline forms part of the reduction of public investment, a typical neo-liberal policy that has been in place for nearly three decades (Sandoval 2004).

In this context, nationalist imaginaries seem to be replacing social ones as the main reference for elaborating an understanding of institutional changes and social relations. In this context, two tasks are particularly difficult. One is how to present to non-specialized audiences how this nationalization of politics influences the way in which Costa Ricans in a more vulnerable situation perceive Nicaraguans as the ones who are taking away their jobs, services, and rights.

The second difficulty is that identification with images of a 'nation threatened' by immigrants is characterized by a strong subjective component while explanations rooted in 'hard data' don't usually approximate the most emotive forms of ascription. Perspectives interested in subjectivity, common to psychoanalysis, deal with hostility as a 'projective identification' that condenses around those who are considered 'others' the sense of fragility that individuals experience in the external world (see Rustin 200I; Clarke 2003; Totton 2006). Unfortunately, at least in the case of Costa 
Rica, these forms of understanding hostility and xenophobia have been more used as an interpretive resource than to guide public intervention strategy. For example, we have no experience in translating this notion of 'identificatory projection' into public discussion in daily life. The absence of debate about the preeminence of nationalism as collective identification and the limited public reflection about the subjective dimension leave space for legitimating the right wing. The 20IO election campaign had as one of its variants the consolidation of a kind of authoritarian populism (Hall I979), in which the Right, which is never named as such, promised zero tolerance and maximum punishments for those who committed crimes, rather than emphasizing the opening up of markets - the latter being a promise that would be unfashionable in the context of the economic crisis. The framing of the campaign drew on a populist repertory in which the icon was a semi-naked man who justified his few belongings as the only way to ensure that he wouldn't be robbed (Sandoval 20IO). Despite the fact that throughout the years 2010 and 201 I the percentage of homicides and the perception of insecurity have diminished, the latter is still considered as the most important problem of the country (Sandoval 20I2b).

Probably the most important consequence of the legitimization of populist authoritarianism is that it became the frame around which the political parties organized their campaigns. The Right ended up presenting itself as in the centre of the political spectrum. The centre-left opposition either didn't try or failed to introduce another vocabulary and other imaginaries (Sandoval 20IO).

A fourth way of addressing xenophobia is rather more practical and based on communal experiences, especially in impoverished neighbourhoods where canteens, health clinics, and educational facilities emerge from the links between churches, NGOs, and communities. Most of these initiatives began as a consequence of cooperative links growing out of the experience of exclusion and the attempt to create institutional facilities that help forge a sense of community. In fact, impoverished communities where Nicaraguans and Costa Ricans live together do not exhibit a nationbased divide. Many families in these communities are mixed, and nationality is not an issue in itself.

Despite the conflicts, rivalries, and contradictions present in the community projects, a social fabric of cosmopolitanism from below is given form around the eating establishments, clinics, and schools. These are the cases of binational communities such as $\mathrm{La}$ Carpio, Barrio Nuevo, or El Triángulo de Solidaridad, situated in Costa Rica's capital. As Mark Goodale (2007: 2I) points out: “...many of the most important actors whose encounters with human rights discourse contribute to its transnationalism never physically leave their villages or towns, or countries". Unfortunately, the image these communities have in the public sphere is of criminalized places. Figuring out how to legitimize a place for its cosmopolitanism-from-below in public speeches is a challenge that may possibly require putting it to music, or into literary and audiovisual fiction. For the time being, these are largely tasks that have been postponed by those working in universities, NGOs, churches, etc.

Recognition of how solidarity and hospitality emerge from daily life could be a priority for intellectual perspectives that prioritize deconstruction, but, as Jonathan Rutherford (2007: I9) notes, "lacked the ethical resources to generate new, more egalitarian social relationships and identities to replace those they sought to undo". A far-reaching challenge, particularly relevant in the study of the imaginaries of immigration, is to become more aware of how to articulate efforts and horizons of hope.

\subsection{Seeking Cosmopolitanism-from- below}

The cosmopolitan is usually conceptualized as a citizen of the world (Tomlinson 1999). Although the term is often used as an alternative to the narrow sense of national or provincial belonging, it has also been noted that it is mainly framed as a "[Male] white/First World take on things" (Massey quoted by Tomlinson I999: I87). As Jonathan Friedman (I997: 81; quoted by Morley 2000: 239) asks, "who can afford a cosmopolitan identity?". Nonetheless, there are also "cosmopolitans in spite of themselves" who forge what might be termed "mundane cosmopolitanism" (Hebdige quoted by Morley 2000: I74). Close to the latter, cosmopolitanism from below aims to envision ways of being which emerge from the experiences of displacement and forced migration. Cosmopolitanism from below emerges from those who do not perceive themselves mainly through narratives of belonging, but who are searching for new ways of being. People living in 'glocal' impoverished communities are learning how to share even when they hold few material resources and are often criminalized.

The analysis of legislation and media imaginaries would unquestionably remain incomplete if the experiences of the migrant community were not simultane- 
ously explored. This experience is often the object of external discourses, but is seldom recognized as the subject of its own enunciation.

'Giving voice to those who have no voice', as it was phrased in Latin America thanks particularly to the vitality of Liberation Theology, is being transformed into the need to listen to these 'others', who have always had a voice but are not recognized as equals. Life stories and other tools of ethnography, for example, are indispensable to inscribe part of the life experiences of the millions of men and women forced to leave their countries in search of opportunities. Community work is easily regarded as 'asistencialismo' (a paternalist, dependency-producing handout approach), unable to transcend immediate needs. Sometimes it is suggested that what is required is more political-oriented work. It has meant a certain division of work among those who undertake community work and those who have more mainstream political priorities. This identification of a local focus with asistencialismo, contrasted to what we could call 'public as political', has been a damaging dichotomy. While the community work could be driven by asistencialismo it also can be an opportunity for those excluded to forge a grounded political culture.

The construction of collective memory growing up around community struggles and efforts is an essential task in terms of political culture. Elizabeth Jelin (2002: 2) suggests that memories are subjective processes, anchored in experiences and in symbolic and material frameworks, and are objects of dispute, conflict, and struggle. Thus they change over time and with that the sense of the past varies. "There is an active political struggle around the sense of what occurred, but also about the sense of memory itself" (Jelin 2002: 6), she argues. Memory as socio-historical construction is a referent for the construction of collective subjectivities and identities. "Identities and memories are not things we think about, but things we think with" (Gillis 1994, quoted in Jelin 2002: 25). As Richard Johnson and his colleagues (2004: 264265) also point out, we can only know what we are thinking and feeling when we express it to others, giving it a defined cultural form. That is to say, the lived experience has to be turned into narrative to be communicated.

Collective memory - being able to articulate struggles, efforts, community initiatives - is a precondition for the constitution of political subjects, who are often effaced by the clientelism of traditional political parties and are not considered as peers by the Left. Thus community work, without being named as 'po- litical', is nevertheless so. And what is more important is that, without this grounded political culture, efforts at a national scale cannot go beyond the expression of the critical middle classes. In the terms of de Sousa Santos, collective memory emerges as a way of translating experience into narratives that are to be shared within the local communities. This process of translation seems to require cultural forms (music and videos among others resources) through which new generations would probably be able to reflect creatively on their lived experience.

As well as this, more explicit political work, for instance campaigning for a reform of immigration legislation, needs to be grounded in the local communities. In her critique of the dichotomy between antiracist work, which used to take place more locally, and the anti-globalization initiatives that do not maintain strong links with those displaced by the global forces of capitalism, Alana Lentin (2004: 298) notes:

For these writers, the displacement of the localized refers to the effort to connect local and global which seeks a common project of intellectual and activist resistance against consolidated transnational counterforce: globalization. Nevertheless, their failure to confront the immediacy of the extremely localized difficulties faced by the 'migrant' - conceptualized as a symbol or a movement rather than as an individual - and the negotiations which must take place at the level of the locality in the interests of survival is indicative of the failure of anti-racism to be fully included in the new politics they describe.

So, most of the time the everyday efforts made in local communities are not perceived by mainstream audiences as 'politics'. A major challenge ahead is how to build links between communities through the recognition that sharing experiences would prompt the creation of a variety of networks. Currently, local communities know little of similar efforts in other communities located not far away. On the other hand, proposals to build networks are conceived at national or regional levels and usually are implemented with little reference to local communities. A common consequence is the disposition to 'speak on behalf of migrants' even though migrant communities scarcely know of the organizations that supposedly represent their interests.

This issue of 'who speaks on behalf of whom' introduces the issue of representation. Most of the repertoires intended to contest xenophobia discussed above are part of initiatives undertaken by institutions - NGOs, churches, and UN projects, among others that have weak links with local communities. The few existing organizations of migrants themselves are tiny 
and are characterized by mutual recriminations. It seems that the hostility against migrants and the political polarization of Nicaraguan society has diminished the possibilities of collective action. Additionally, political parties in Nicaragua do not recognize emigration as a challenge for their own agendas and, except in electoral periods, ignore their co-nationals in Costa Rica. What seem to matter are remittances, not those who produce value.

The possibility of larger migrant organizations able to produce their own ways of demanding recognition and distribution in different forums (Fraser 2008) seems to depend on the recognition that any collective action project has to be grounded in the communities. Rather than a fixed agenda and rigid ways of working, collective efforts have to be strategic, based on limits and potentialities. Again, translation, rather than a sort of master plan, seems to be the key. However, translation implies actors who are able to be present at different scales. The intellectual division of work between community work and national or international advocacy is without reservation an impediment for translating agendas and the triangulation of efforts. In other words, the challenge not only refers to ideas or proposals but also to the 'situatedness' of academic, social, and political actors. Migrant communities are impoverished and share a vast number of limitations, but at the same time they are vital to a number of key economic activities. In interviewing women who work in the pineapple industry Costa Rica is the leading world exporter - they recounted how they stopped a pineapple processing plant because they did not receive a minimum wage. Instead their income was based on the amount of fruit selected, and they received very little money if the number of fruits selected for export declined. So they wrote a letter to justify their refusal to continue working. The managers agreed to change the payment scheme (Sandoval/Brenes/Paniagua 20I2). Such experiences have to be channelled into a long-term effort of constituting political subjects, and social science research can contribute to this.

The key may reside in the articulation of efforts and mobilizations rather than in mutual disqualification. One step in the linking work may consist of facilitating possibilities for political formation in communities, so that those who participate in community initiatives may also acquire competencies to participate in national or regional networks. In other words, independent of the migratory condition, pedagogical processes need to be facilitated that strengthen what Davis, Martínez, and Warner (2010: 87) call "substan- tive citizenship" (in contrast to formal citizenship, according to which people are seen as having an irregular status or are residents, etc.) - initiatives through which people can participate in their barrios, making use of public spaces, as well as participating in political actions on a broader scale.

Cosmopolitanism from below seems to be essential to any larger project of politics, in terms of envisioning ways of work, content, and form. Cultural forms through which contestation can take place have so far been barely discussed. The capacity to identify cultural forms that can appeal to people to recognize what Costa Rica's most vulnerable groups have in common with the migrant community is a key political challenge. The possibility of accomplishing this depends, again, on a close relationship with the local communities.

\subsection{Conclusions}

For the research team that has been involved in studying Nicaraguan migrants in Costa Rica, various challenges have come up in the attempt to intervene in policy formulation, the critique of imaginaries, and community work. The first one refers to the ethical dimension, and relates to the responsibility that follows from listening. In other words, listening does not just involve attentively following what the migrants are saying, but it also involves raising questions about the ways in which what was said could be translated to decision-makers. Here there seems to be an important challenge for the social sciences, since needs assessments are frequent, and most often agree in their main conclusions, but there is usually no great willingness to follow up on the demands that are identified.

A second challenge consists of the possibilities of creating work teams in which colleagues with different backgrounds can contribute to the research work and the ways in which the main findings can influence public policies, but also to the political work in a broader sense. The demands posed by the communities recall the tensions that arise from the relations between those social science perspectives most centred on analytical or comprehensive perspectives and those most interested in normative perspectives. Such tensions become more alive when what they are dealing with is not so much reproducing the analytical/normative distinction, but linking and articulating findings and policy-making (or politics) based on concrete situations and cases. 
A third challenge refers to the possibilities that one can advocate public policy formulation based on research. It is not hard to recognize that there is often mutual resistance between policy formulators and those of us who do academic research, above all at times like today, when policies maintain an accentuated orientation in general neo-liberal terms and academic research defends critical analysis. Nonetheless, based on the work experience around the Migration Law and its regulations, it is worth insisting that advocacy must not be discarded. Although the results are limited, it is even more limiting to assume that the social sciences only consist of critically assessing the country's development style without attempting to use the knowledge gained to influence the course it is taking. While it is possible to intervene in the course of processes, it involves recognizing that those possibilities are limited in certain topics and institutional contexts and are greater in others. It is also important to recognize that in the process of demanding, the collective effort becomes visible, while also making visible the agendas they are trying to legitimize. That is, the stakeholders and agendas are not preconfigured ahead of time; there is a learning process and an

\section{References}

Asamblea Legislativa de la República de Costa Rica, 2009: Ley de migración y extranjería $\mathrm{N}^{\circ} 8764$ (San José).

Bakhtin, Mikhail, 198I: The Dialogic Imagination: Four essays by M.M. Bakhtin [Michael Holquist (Ed.); Caryl Emerson and Michael Holquist (translators)] (Austin: University of Texas Press).

Benhabib, Seyla, 2004: The Rights of Others. Aliens, Residents and Citizens (Cambridge: Cambridge University Press).

Bhattacharyya, Gargi, 2008: Dangerous Brown Men. Exploiting Sex, Violence and Feminism in the War of Terror (London: Zed).

Bhattacharyya, Gargi; Gabriel, John; Small, Stephen, 2002: Race and Power. Global racism in the twenty-first century (London: Routledge).

Bolaños, Olman; Brenes, Mónica; Paniagua, Laura; Sandoval, Carlos, 20II: Un país en donde quepa toda la gente. Derechos y responsabilidades de las personas migrantes en Costa Rica (San José: Lara y Segura).

Bourdieu, Pierre; Wacquant, Loic, I992: An Invitation to Reflexive Sociology (Chicago: University of Chicago Press).

Brenes, Mónica; Fernández, Karen; Paniagua, Laura; Sandoval, Carlos, 20I0: Ciudadanías en práctica. El ejercicio de los derechos de personas migrantes en Costa Rica en la Sala Constitucional (San José: CONAMAJ).

Burawoy, Michael, 2005: "For Public Sociology" in: American Sociological Review, 70: 4-28. accumulation of capacities indispensable to future efforts to legitimate new demands. The translation of international law and constitutional law into the analysis of migration legislation can be mentioned as a case in point. Similarly, ways can be recounted in which social science can call into question public policies that used to be taken for granted. A last example might be the challenge of articulating community projects which give material support to impoverished communities often inhabited by migrants, and political education through which those who join the initiatives can recognize the sources of their everyday misfortunes.

A fourth challenge, incipient in the experiences narrated here, refers to the ways migrants themselves can join with the institutions in advocacy work so that the formulation of demands does not fall exclusively to those who work in universities, NGOs, churches, and other institutions. In some cases more than in others, the participation of community members has been incorporated into some of the initiatives described here. But without doubt, the integration of broader collectives should not be considered a second-rate priority.

Burawoy, Michael, 2007: "The Field of Sociology: Its Power and Its Promise”, in: Clawson, Dan; Zussman, Robert; Misra, Joya; Gerstel, Naomi; Stokes, Randall (Eds.): Public Sociology. Fifteen eminent sociologists debate politics of the profession in the twenty-first century (Berkeley: University of California Press).

Chavez, Leo, 200I: Covering Immigration: Popular Images and the Politics of the Nation (Berkeley: California University Press).

Chavez, Leo, 2008: The Latino Threat. Constructing immigrants, citizens, and the nation (Berkeley: University of California Press).

Clarke, Simon, 2003: Social Theory, Psychoanalysis and Racism (London: Palgrave).

Davis, Stephen; Martínez, Juan; Warner, Stephen, 20I0: "The Role of the Catholic Church in the Chicago Immigrant Mobilization", in: Pallares, Amalia; FloresGonzález, Nilda (Eds.): ¡Marcha! Latino and the Immigrant Rights Movenment (Champaign, IL: University of Illinois Press).

DeGenova, Nicholas, 2002: "Migrant 'illegality' and deportability in everyday life", in: Ann. Review of Anthropology, vol: I4I9-I447.

De Sousa Santos, Boaventura, 2009: Epistemologías desde el Sur (Buenos Aires: CLACSO).

De Sousa Santos, Boaventura, 20I0: "Prólogo", in: Pazmiño Freire, Patricio (Eds.): Del Activismo Social a la Justicia Constitucional (Quito: FLACSO). 
Fanon, Franz, 1986: Black Skin, White Masks (London: Pluto).

Fraser, Nancy, 2008: Scales of Justice. Reimagining Political Space in a Globalizing World (Cambridge: Polity Press).

Friedman, J., I997: "Global crises, the struggle for identity, and intellectual pork-barrelling”, in: Werbner, P.; Modood, T. (Eds.): Debating Cultural Hybridity (London: Zed): 70-89.

Gillis, John, 1994: "Memory and identity: the history of a relationship", in: Gillis, John R. (Ed.): Commemorations: The Politics of National Identity (Princeton: Princeton University Press).

Goodale, Marc, 2007: "Locating Rights. Envisioning Law between the Global and the Local", in: Goodale, Marc; Engle, Merry Sally (Eds.): The Practice of Human Rights. Tracking Law between the Global and the Local (Cambridge, MA: Cambridge University Press).

Green, Michael, 1997: "Working practices", in: McGuigan, Jim (Ed.): Cultural Methodologies (London: Sage).

Hage, Ghassen, 1998: White fantasies (Sydney: Pluto Press).

Hall, Stuart, I979: "The Great Moving Right Show" in Marxism Today, January.

Hall, Stuart, 198r: "The Whites of their Eyes: Racist Ideologies and the Media", in: Bridges, George; Brunt, Rosalind (Eds.): Silver Linings: Some Strategies for the Eighties (London: Lawrence and Wishart). Reprinted 1990 in: Alvarado, Manuel; Thompson, John (Eds.): The Media Reader (London: British Film Institute).

Hays, Sharon, 2007: "Stalled at the Altar? Conflict, Hierarchy, and Compartmentalization in Burawoy's Public Sociology”, in: Clawson, Dan; Zussman, Robert; Misra, Joya; Gerstel, Naomi; Stokes, Randall (Eds.): Public Sociology. Fifteen eminent sociologists debate politics of the profession in the twenty-first century (Berkeley: University of California Press).

Hebdige, Dick, I990: "Fax to the future", in: Marxism Today, January: 20.

Hill Collins, Patricia, 2007: "Doing the Sociology That Had No Name”, in: Clawson, Dan; Zussman, Robert; Misra, Joya; Gerstel, Naomi; Stokes, Randall: Public Sociology. Fifteen eminent sociologists debate politics \& the profession in the twenty-first century (Berkeley: University of California Press).

Hobsbawm, Eric, 1998: “The Death of Neoliberalism”, in: Marxism Today, Nov/Dec.

INEC [Instituto Nacional de Estadística y Censos], 20II: Encuesta Nacional de Hogares. Cifras básicas sobre fuerza de trabajo, pobreza e ingresos (San José: INEC, July).

Jelin, Elizabeth, 2002: Los trabajos de la memoria (Madrid: Siglo XXI).

Johnson, Richard; Chambers, Deborah; Raghuram; Parvati; Tincknell; Estella, 2004: The Practice of Cultural Studies (London: Sage).

La Nación, 20II: "Me venía preparando para atender algo muy complicado”, in: 27 August.
Lentin, Alana, 2004: Racism \& Anti-racism in Europe (London: Pluto).

Lipsitz, George, 1999: The Possessive Investment in Whiteness. How White People Profit from Identity Politics (Philadelphia: Temple University Press).

Marcenaro, Petronio, 2007: Al otro lado del Río San Juan (San José: Editorial Costa Rica).

Massey, Doreen, 1994: Space, Place and Gender (Cambridge: Polity Press).

Mills, Charles Wright, 1987: La imaginación sociológica (México: Fondo de Cultura Económica).

Mora, Tatiana, 2000: Poverty matters, but to what extent? Perceptions of poverty through the literary discourse in Costa Rica (The Hague: Institute for Social Studies, Working Paper No. 3IO; <http://repub.eur.nl/res/pub/ I9055/wp3IO.pdf>.

Morley, David, 2000: Home Territories. Media, Mobility and Identity (London: Routledge).

Nakano Glenn, Evelyn, 2007: "Whose Public Sociology? The Subaltern Speaks, but Who Is Listening?”, in: Clawson, Dan; Zussman, Robert; Misra, Joya; Gerstel, Naomi; Stokes, Randall (Eds.): Public Sociology. Fifteen eminent sociologists debate politics \& the profession in the twenty-first century (Berkeley: University of California Press).

Ngai, Mae M., 2004: Impossible Subjects: Illegal Aliens and the Making of Modern America (Princeton, NJ: Princeton University Press).

Paniagua, Flory, 20I0: La embajadora de la ciudad de las naranjas en Costa Rica (Heredia: Litografía Morales).

Press Conference, 20I2: "La Ley de Migración en Costa Rica: A dos años de su entrada en vigencia. Promesas, realidades y desafíos", San José: 28 March.

Rustin, Michael, 200I: Reason and Unreason. Psychoanalysis, Science and Politics (London - New York: Continuum Books).

Rutherford, Jonathan, 2007: After Identity (London: Lawrence and Whishart).

Sandoval, Carlos, 2004: Threatening Others. Nicaraguans and the formation of national identities in Costa Rica (Athens: Ohio University Press).

Sandoval, Carlos, 2009a: "Narrating lived experience in a binational community in Costa Rica”, in: Bhattacharyya, Gargi (Ed.): Ethnicities and values in a changing world (London: Ashgate).

Sandoval, Carlos, 2009b: "Zonas de contacto entre las ciencias sociales", in: Cook, Elizabeth (Ed.): Género y Religión, Sospechas y aportes para la reflexión (San José: Universidad Bíblica Latinoamericana).

Sandoval, Carlos, 20ıо: "Costa Rica: El triunfo de Chinchilla sella veinte años de derechización”, in: Envío, 29,344: 32-39.

Sandoval, Carlos, 20I2a: "Contestar la hostilidad antinmigrante en Costa Rica: Un proyecto de ciencias sociales públicas en curso", in: Mirian Llona (Ed.): Entreverse. Teoría y metodología práctica de las Fuentes orales (Bilbao, University of the Basque Country). 
Sandoval, Carlos, 20I2b: "De Calero a la Trocha. La nueva disputa limítrofe entre los gobiernos de Costa Rica y Nicaragua (20IO-20I2)", in: Anuario de Estudios Centroamericanos, 38: I77-I92.

Sandoval, Carlos, 20I2c: "Presentación", in: Huhn, Sebastian (Ed.): Criminalidad y discurso en Costa Rica. Reflexiones críticas sobre un problema social (San José: FLACSO).

Sandoval, Carlos; Brenes, Mónica; Masís, Karen; Paniagua, Laura; Sánchez, Esteban, 2007: Nuestras vidas en La Carpio. Aportes para una historia popular (San José: Editorial de la Universidad de Costa Rica).

Sandoval, Carlos; Brenes, Mónica; Masís, Karen; Paniagua, Laura, 20Io: Un país fragmentado. La Carpio: Cultura, comunidad y política (San José: Editorial de la Universidad de Costa Rica).

Sandoval, Carlos; Brenes, Mónica; Paniagua, Laura, 20I2: La dignidad vale mucho. Mujeres nicaragüenses forjan derechos en Costa Rica (San José: Editorial de la Universidad de Costa Rica).

Tomlinson, John, I999: Globalization and Culture (Cambridge: Polity Press).

Totton, Nick, 2006: "Conflict, competition and aggression”, in: Totton, Nick (Ed.): The Politics of Psychotherapy (Berkshire: Open University Press).

Williams, Raymond, 1977: Marxism and Literature (Oxford: Oxford University Press).

Open Access. This chapter is distributed under the terms of the Creative Commons Attribution Non-commercial License, which permits any noncommercial use, distribution, and reproduction in any medium, provided the original author(s) and source are credited. 